\title{
PERSEPSI PELAKU USAHA UMKM TENTANG TARIF FINAL 1\% MENJADI TARIF FINAL 0,5\% DI KOTA BANDUNG
}

\author{
Kasir dan Deni Hamdani \\ Sekolah Tinggi Ilmu Ekonomi Indonesia Membangun, (STIE INABA) Bandung, \\ Jl. Soekarno Hatta No. 448 Bandung - Indonesia \\ E-mail: kasir@inaba.ac.id
}

\begin{abstract}
ABSTRAK. Perkembangan pelaku usaha UMKM di Indonesia saat ini mengalami kemajuan.Ada 59,2 juta UMKM, dan telah menyerap tenaga kerja nasional 97\% serta memberikan kontribusi PDB 57\%. Juga untuk wilayah Propinsi Jawa Barat, khususnya di Kota Bandung, pelaku usaha sentra UMKM menurut Dinas Perdagangan dan Perindustrian tahun 2017 terdapat 1.235 unit. Dengan jumlah pelaku usaha UMKM yang meningkat tersebut, tentunya berpotensi untuk dijadikan sebagai sumber pendapatan baik untuk pemerintah pusat maupun pemerintah daerah yang dalam hal ini adalah berupa pendapatan pajak.Kebijakan-kebijakan pemerintah yang dikeluarkan berkenaan dengan, semaksimal mungkin harus dapat dipahami oleh para pelaku usaha khususnya UMKM.Karena pelaku usaha UMKM tersebut, biasanya masih minim dalam pemahaman perpajakan.Sehingga, apabila pelaku usaha tersebut paham dan sadar. Maka mereka mau untuk membayar pajak atas usaha yang dilakukannya. Metode yang digunakan yaitu menggunakan pendekatan kuantitatif melalui metode survey padapelaku usaha sentra UMKM yang tersebar di Kota Bandung. Sampel yang digunakan menggunakan rumus Slovin dengan tingkat kepercayaan $90 \%$. Sedangkan metode teknik sampling yang digunakan adalah metode probability sampling, dancara pengambilan sampel yaitu dengan carasimple random sampling. Sehingga dalam penelitian ini menghasilan sampel sebanyak 93 pelaku usaha sentra UMKM yang tersebar di kota Bandung. Hasil penelitian menunjukan bahwa sebagian pelaku usaha sentra UMKM di Kota Bandung (daerah Cibaduyut, Sukagalih dan Cihampelas) tidak menyetujui adanya penerapan tarif Final sebesar 0,5\% maupun perubahan tarif Final dari 1\% menjadi 0,5\%. Hal ini terjadi kurangnya respon pelaku usaha sentra UMKM terhadap kebijakan perpajakan yang dikarenakan kurangnya sosialisasi mengenai kebijakan perpajakan yang dikeluarkan oleh Dirjen Pajak.
\end{abstract}

Kata kunci: Pelaku UMKM; Pemahaman; Tarif; Final

\section{PERCEPTION OF MSME BUSINESS CONCERNING FINAL RATES 1\% TO FINAL RATES $0.5 \%$ IN BANDUNG CITY}

\begin{abstract}
The development of SMEs in Indonesia is currently experiencing progress. There are 59.2 million MSMEs, and have absorbed $97 \%$ of the national workforce and contributed $57 \%$ of GDP. Also for the area of West Java Province, especially in the city of Bandung, according to the Trade and Industry Office in 2017 there are 1,235 units of MSME centers. With the increasing number of MSME entrepreneurs, it certainly has the potential to be used as a source of income for both the central and regional governments, which in this case is in the form of tax revenue. Government policies issued with regard to, as much as possible must be understood by business actors, especially MSMEs. Because these MSME entrepreneurs, usually are still minimal in understanding taxation.So, if the business actor understands and is aware. Then they want to pay taxes on the business they do. The method used is using a quantitative approach through a survey method for MSME business center operators spread across the city of Bandung. The sample used uses the Slovin formula with a $90 \%$ confidence level. While the sampling technique method used is the probability sampling method, and the sampling method is simple random sampling. So that in this study produced a sample of 93 entrepreneurs of MSME centers scattered in the city of Bandung. The results showed that some MSME business center operators in the city of Bandung (Cibaduyut, Sukagalih and Cihampelas areas) did not approve of the application of a final tariff of $0.5 \%$ or a final tariff change from $1 \%$ to $0.5 \%$. This is due to the lack of response of MSME center business actors to tax policies due to lack of socialization regarding tax policies issued by the Director General of Taxes.
\end{abstract}

Key words: Business Actors; MSME; Understanding; Tariff; The final

\section{PENDAHULUAN}

Meningkatnya kebutuhan negara dalam pemenuhan pendanaan pembangunan nasional yang diperoleh dari sektor pajak, maka pajak memegang peranan dan fungsi yang sangat penting dan strategis bagi kehidupan bangsa dan negara. Karena tanpa adanya pajak, maka bisa dipastikan sebagian besar kegiatan negara akan sulit untuk dapat dilaksanakan. Penggunaan uang pajak yang diterima dari masyarakat meliputi untuk pengeluaran belanja pegawai sampai dengan pembiayaan berbagai proyek pembangunan untuk kepentingan masyarakat seperti jembatan, sekolah, puskesman/rumah sakit, jalanjalan, kantor-kantor pemerintahan. Dan juga pajak bisa digunakan untuk memberikan subsidi kepada masyarakat yang kurang mampu dan membantu pelaku usaha UMKM baik dalam pemberian modal kerja termasuk pembinaannya. Pencapaian target penerimaan pajak yang merupakan ukuran kuantitatif kenerja Direktorat Jendral Pajak yang harus dilaksanakan dengan sebaik-baiknya. Dimana sesuai dengan tugas dan fungsinya berkewajiban untuk melakukan pelayanan, penyuluhan, pembinaan dan pengawasan dalam rangka memaksimalkan penerimaan pajak dari para wajib pajak termasuk wajib pajak UMKM. 
UMKM (Usaha Mikro, Kecil dan Menengah) merupakan pelaku usaha yang tahan banting saat perekonomian dilanda krisis moneter. Hal ini terlihat saat terjadinya krisis moneter pada tahun 1997-1998, dimana banyak perusahaan-perusahaan menengah ke atas yang bangkrut, hanya UMKM yang mampu tetap berdiri kokoh. Pelaku Usaha Mikro, Kecil dan Menengah (UMKM) mempunyai peran penting dan strategi dalam pembangunan ekonomi nasional. Selain berperan dalam pertumbuhan ekonomi dan penyerapan tenaga kerja, UMKM juga berperan dalam mendistribusikan hasil-hasil pembangunan, apalagi dari tahun ke tahun jumlahnya mengalami kenaikan. Menurut data BPS, bahwa saat ini ada sekitar 59,2 juta pelaku UMKM dimana telah menyerap tenaga kerja secara nasional sekitar 97\% dan memberikan kontribusi PDB sekitar 57\%.

Dengan melihat jumlah pelaku usaha UMKM yang semakin meningkat tersebut, tentunya bisa dijadikan sebagai sumber pendapatan baik bagi pemerintah pusat maupun pemerintah daerah, yang dalam hal ini berupa pendapatan pajak.Dimana nantinya pajak yang diterima negara dapat dipergunakan untuk kesejahteraan rakyat Indonesia.

Sosialisasi sebenarnya merupakan sarana komunikasi antara fiskus dan wajib pajak juga, sehingga segala keluhan wajib pajak dapat ditampung dan dicarikan solusinya. Dan kebijakan terbaru untuk UMKM yang dituangkan dalam Peraturan Pemerintah (PP) Nomor 23 tahun 2018 ini adalah jalan keluar terbaik menanggapi keluhan kalangan UMKM terkait tarif pajak yang selama ini kerap terdengar. Karena bagi mereka yang menjalankan usaha dengan modal terbatas dan omset tak lebih dari Rp4,8 miliar setahun, Tarif Pajak Final satu persen itu cukup memberatkan. Dan pemerintah telah merespon segala keluhan itu dengan memangkas Tarif Pajak untuk UMKM kebijakan tarif PPh final yang selama ini menurut pelaku usaha UMKM masih terasa berat. Maka pemerintah saat ini mengeluarkan kebijakan mengenai perubahan tarif pajak final dimana tarif $\mathrm{PPh}$ final yang sebelumnya sebesar 1\% mulai bulan Juli 2018 menjadi $0,5 \%$.

Untuk kebijakan perubahan tarif $\mathrm{PPh}$ final tersebut tentunya sangat direspon dengan baik oleh para pelaku usaha UMK, terlebih yang berada di Kota Bandung khususnya di sentra-sentra usaha. Dimana saat sekarang sesuai dengan data yang berasal dari Dinas Perdagangan dan Perindustrian Kota Bandung, bahwa jumlah pelaku usaha sentra UMKM untuk tahun 2017 adalah sebanyak 1.235 pelaku usaha yang tersebar di beberapa kecamatan di Kota Bandung.

Dengan adanya kebijakan perubahan tarif $\mathrm{PPh}$ final tersebut, maka para pelaku usaha sentra UMKM di Kota Bandung tentunya bisa untuk mempelajari dan memahaminya. Sehingga pajak yang nantinya harus dibayar ke kas negara akan lebih kecil dari yang sebelum adanya perubahan tarif.

Dengan melihat latar belakang tersebut, maka penulis tertarik untuk meneliti persepsi kebijakan perubahan tarif $\mathrm{PPh}$ final dari yang sebelumnya $1 \%$ menjadi $0,5 \%$ pada pelaku usaha sentra UMKM yang tersebar di beberapa kecamatan di Kota Bandung.

Pengertian UMKM menurut Bank Indonesia (2012) menyebutkan:

1. Usaha Mikro adalah usaha produktif milik orang perorangan dan/atau badanusaha perorangan yang memiliki kekayaan bersih paling banyak lima puluh juta rupiah tidak termasuk tanah dan bangunan tempat usaha; atau memiliki hasil penjualan tahunan paling banyak tiga ratus juta rupiah

2. Usaha Kecil adalah usaha ekonomi produktif yang berdiri sendiri, yang dilakukan oleh orang perorangan atau badan usaha yang bukan merupakan anak perusahaan atau bukan cabang perusahaan yang dimiliki, dikuasai,atau menjadi bagian baik langsung maupun tidak langsung dari usaha menengah atau usaha besar yang memiliki kekayaan bersih lebih dari lima puluh juta rupiah sampai dengan paling banyak lima ratus juta rupiah tidak termasuk tanah dan bangunan tempat usaha; atau memiliki hasil penjualan tahunan lebih dari tiga ratus juta rupiah sampai dengan paling banyak (dua milyar lima ratus juta rupiah).

3. Usaha Menengah adalah usaha ekonomi produktif yang berdiri sendiri, yang dilakukan oleh orang perorangan atau badan usaha yang bukan merupakan anak perusahaan atau cabang perusahaan yang dimiliki, dikuasai, atau menjadi bagian baik langsung maupun tidak langsung dengan usaha kecil atau usaha besar dengan jumlah kekayaan bersih atau hasil penjualan memiliki kekayaan bersih lebih dari lima ratus jutarupiah sampai dengan paling banyak sepuluh milyar rupiah tidak termasuk tanah dan bangunan tempat usaha; atau memiliki hasil penjualan tahunan lebih dari dua milyar lima ratus juta rupiah) sampai dengan paling banyak lima puluh milyar rupiah.

Berbagai pengertian pajak telah ditulis oleh beberapa ahli, diantaranya menurut Mardiasmo (2016:1) pajak adalah iuran rakyat kepada Negara berdasarkan undangundang (yang dapat dipaksakan) dengan tiada mendapat jas timbul (kontraprestasi) yang langsung dapat ditunjukan dan digunakan untuk membayar pengeluaran umum. Dan juga menurut Definisi pajak menurut Undang Undang Nomor 28 Tahun 2007 Tentang Ketentuan Umum dan Tata cara Perpajakan (UU KUP) bahwa Pajak adalah kontribusi wajib kepada negara yang terutang oleh orang pribadi atau badan yang bersifat memaksa berdasarkan 
Undang-Undang, dengan tidak mendapatkan imbalan secara langsung dan digunakan untuk keperluan negara bagi sebesar-besarnya kemakmuran rakyat.

Fungsi pajak menurut Waluyo (2014:6) adalah sebagai fungsi penerimaan (budgeter) dan fungsi mengatur (reguler). Sedangkan sistem pemungutan pajak menurut Diana Sari (2013:78) adalah dengan menggunakan official-assessment system(besarnya pajak terutang yang menentukan fiskus), self-sssessment(fiskus memberikan wewenang kepada wajib pajak untuk menentukan sendiri besarnya pajak terutang), witholding sistem (pajak terutang ditentukan oleh pihak ketiga selain fiskus dan wajib pajak)

Pajak Penghasilan (PPh) adalah pajak yang dikenakan terhadap Subyek Pajak atas penghasilan yang diterima atau diperoleh dalam tahun pajak tertentu (UU No. 36 tahun 2008).

Dalam Peraturan Pemerintah Nomor 23 Tahun 2018 menjelaskan peraturan yang mengatur tentang pajak penghasilan atas penghasilan dari usaha yang diterima atau diperoleh wajib pajak yang memiliki peredaran bruto tertentu dan bersifat final dengan tarif final $0,5 \%$ dan berlaku mulai tanggal 1 Juli 2018 dengan kriteria sbb :

1. Sesuai dengan pasal 2 ayat 3 menyatakan bahwa: Tidak termasuk penghasilan dari usaha yang dikenai Pajak Penghasilan yang bersifat final sebagaimana dimaksud pada ayat (1) sebagai berikut: a. penghasilan yang diterima atau diperoleh Wajib Pajak orang pribadi dari jasa sehubungan dengan pekerjaan bebas; b. penghasilan yang diterima atau diperoleh di luar negeri yang pajaknya terutang atau telah dibayar di luar negeri; c. penghasilan yang telah dikenai Pajak Penghasilan yang bersifat final dengan ketentuan peraturan perundangundangan perpajakan tersendiri; dan d. penghasilan yang dikecualikan sebagai objek pajak.

2. Sesuai dengan pasal 3 ayat 1 menyatakan bahwa :Wajib Pajak yang memiliki peredaran bruto tertentu yang dikenai Pajak Penghasilan final sebagaimana dimaksud dalam Pasal 2 ayat (1) merupakan: a. Wajib Pajak orang pribadi; dan b. Wajib Pajak badan berbentuk koperasi, persekutuan komanditer, firma, atau perseroan terbatas, yang menerima atau memperoleh penghasilan dengan peredaran bruto tidak melebihi empat milyar delapan ratus juta rupiah dalam 1 (satu) Tahun Pajak.

3. Sesuai dengan pasal 5 ayat 1 menyatakan bahwa: Jangka waktu tertentu pengenaan Pajak Penghasilan yang bersifat final sebagaimana dimaksud dalam Pasal 2 ayat (1) yaitu paling lama:

a. 7 (tujuh) Tahun Pajak bagi Wajib Pajak orang pribadi; a. 4 (empat) Tahun Pajak bagi Wajib Pajak badan berbentuk koperasi, persekutuan komanditer, atau firma; dan

b. (tiga) Tahun Pajak bagi Wajib Pajak badan berbentuk perseroan terbatas.
Definisi persepsi dikemukan oleh Kothler (2013: 179), dimana menjelaskan bahwapersepsi adalah dimana kita memilih, mengatur, dan menterjemahkan masukan informasi untuk menciptakan gambaran dunia yang berarti. Sehingga dari pengertian persepsi tersebut diatas dapat disimpulkan bahwa persepsi yaitu suatu proses dalam menggunakan sesuatu yang dapat diterima oleh individu agar setiap individu dapat memilih, mengatur dan menerjemahkan suatu informasi untuk menciptakan gambaran dunia yang berarti.

Faktor-faktor yang mempengaruhi persepsi dalam individu adalah faktor internal yaitu faktor yang terdapat dalam individu misalkan fisiologis, perhatian, minat, kebutuhan searah, pengalaman dan ingatan, suasana hati. Sedangkan faktor eksternal yatu lingkungan dan objekobjek yang terlihat didalamnya misalnya ukuran dan penempatan dari objek, warna dari objek, keunikan dan kekontrasan, intensitas dan kekuatan, motivasi atau gerakan

Berikut indikator-indikator dalam mengukur penerapan tarif PPh Finalsebagai berikut:

1. Pengetahuan Wajib Pajak terkait ketentuan umum PP No. 23 Tahun 2018 yang meliputi pemberlakuan peraturan dan isi peraturan (objek dan subjek yang dikenai peraturan).

2. Sikap Wajib Pajak terhadap tujuan yang telah ditetapkan oleh pemerintah dengan adanya PP No. 23 Tahun 2018

3. Pengetahuan Wajib Pajak terkait ketentuan umum perubahan PP No. 46 Tahun 2013 menjadi PP No. 23 Tahun 2018 yang meliputi pemberlakuan peraturan dan isi peraturan (objek dan subjek yang dikenai peraturan).

4. Kemampuan wajib pajak secara teknis berkaitan dengan peraturan yang baru PP No. 23 Tahun 2018 baik dalam tata cara perhitungannya maupun dalam pelunasannya.

Berikut alur penentuan omset penjualan yang dikenakan sesuai dengan PP Nomor 23 Tahun 2018.

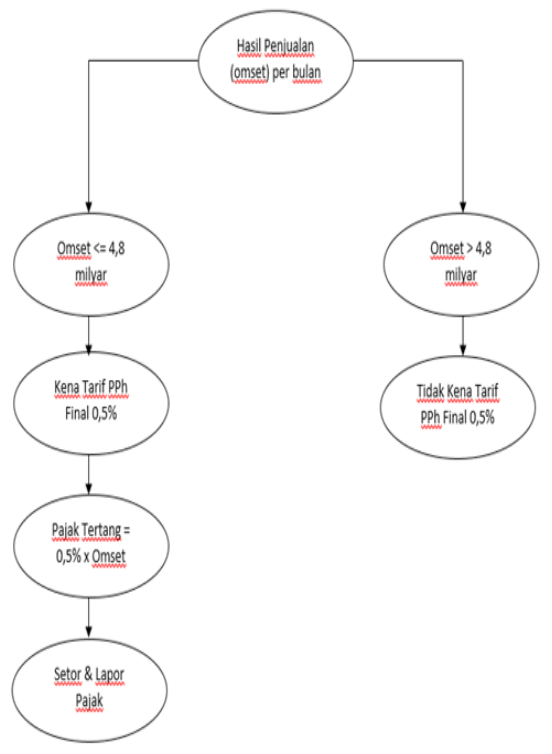

Sumber : Hasil Data Olahan 
Beberapa penulis yang menulis tentang UMKM dilakukan oleh Faizara Prabantari, Moh. Didik Ardiyanto (2017), mengemukakan hasilnya bahwa mayoritas UMKM yang berada di Jawa Tengah dan Daerah Istimewa Yogyakarta dengan pendapatan kotor hingga Rp 4.800.000.000 per tahun merasa tidak menguntungkan atas PP 46/2013 dan lebih suka menggunakan tarif UU 36/2008. Dan menguntungkan pembayar pajak tetapi akan menurunkan penerimaan pajak dan dapat merugikan pembayar pajak tetapi akan meningkatkan penerimaan pajak. Muhammad Syafiqurrahman, Agus Budiatmanto, Anis Widjajanto, Anas Wibawa, Doddy Setyawan, Rizky Akbar Anwar (2017) hasilnya adalah Penerapan Peraturan Pemerintah Nomor 46 Tahun 2013 membawa kemudahan dan penyederhanaan perhitungan pajak wajib pajak, sehingga para wajib pajak UMKM semakin mudah menghitung dan membayar pajaknya.

Fitari Vidia Yanuswari(2016), hasilnya adalah sebagian wajib pajak merasa menguntungkan terhadap pelaksanaan PP No. 46. Sementara itu, beberapa bagian dari wajib pajak merasa dirugikan terhadap pelaksanaan PP No. 46 sehingga mereka tidak tertarik untuk menggunakan PP No. 46. Dan yang dilakukan oleh N. L. Supadmi, D. G Dharma Suputra (2016), hasilnya adalah persepsi wajib pajak pada penerapan nomor regulasi. 46 tahun 2013 dan berpengaruh positif signifikan terhadap kepatuhan pajak UMKM di Denpasar. Ini berarti persepsi yang lebih baik dari wajib pajak pada penerapan nomor regulasi. 46 tahun 2013, maka para wajib pajak UMKM di Denpasar akan lebih taat dalam memenuhi kewajiban perpajakannya

\section{METODE}

Metode penelitian merupakan metode untuk menentukan kebenaran yang merupakan sebuah pemikiran yang kritis. Penelitian tentunya mempunyai tujuan dan kegunaan tertentu. Melalui penelitian manusia dapat memanfaatkan hasil penelitiannya, secara umum data yang diperoleh dapat digunakan utuk memahami, memecahkan, dan mengantisipasi masalah yang dihadapi.

Menurut Sugiyono (2017:2) mengemukakan yang dimaksud dengan metode penelitian adalah sebagai berikut: "Metode penelitian pada dasarnya merupakan cara ilmiah untuk mendapatkan data dengan tujuan dan kegunaan tertentu."

Jenis penelitian ini menggunakan metode kuantitatif dengan penelitian survey. Menurut Sugiyono (2017:7) Metode kuantitatif adalah: "Metode kuantitatif dapat diartikan sebagai metode pasitivistik karena berlandasan pada filsafat positivisme. Metode ini sebagai metode ilmiah/scintific karena telah memunuhi kaidah-kaidah ilmiah yaitu konkrit/ empiris, objektif, terukur, rasional, dan sistematis. Metode ini juga disebut metode discovery, karena dengan metode ini ditemukan dan dikembangkan berbagai iptek baru. Metode ini disebut metode kuantitaif karena data dan penelitian berupa agka-angka dan analisis menggunakan statistik."

Menurut Sugiyono (2017:6) bahwa: "Metode survey merupakan metode yang digunakan untuk mendapatkan data dari tempat tertentu yang alamiah (bukan buatan), tetapi peneliti melakukan perlakuan dalam pengumpulan data, misalnya dengan mengedarkan kuesioner, test, wawancara terstruktur dan sebagainya".

Menurut Sugiyono (2017:11), mengemukakan pengertian kedua penelitian tersebut adalah sebagai berikut: penelitian deskriftif adalah penelitian yang dilakukan untuk mengetahui nilai variabel baik satu variabel atau lebih (independent) tanpa membuat pembandingan atau hubungan dengan variabel lain. Sedangkan penelitian verifikatif adalah suatu penelitian yang ditujukan untuk menguji teori dan akan mencoba menghasilkan metode ilmiah yakni status hipotesa yang berupa kesimpulan, apakah suatu hipotesa diterima atau ditolak. Penelitian verifikatif merupakan penelitian yang digunakan untuk menguji hipotesis dengan menggunakan perhitungan statistik.

Dalam penelitian ini metode deskriftif digunakan untuk mengetahui dan mengkaji bagaimana pendapat pelaku usaha sentra UMKM di Kota Bandung mengenai tarif final $0,5 \%$ di Peraturan Pemerintah Nomor 23 Tahun 2018 dan perubahan tarif final 1\% menjadi 0,5\%. Sedangkan metode verifikatif digunakan untuk mengetahui dan mengkaji besarnya pengaruh persepsi pelaku usaha sentra UMKM di Bandung tentang tarif final $0,5 \%$ dan perubahan tarif final $1 \%$ menjadi $0,5 \%$. Jenis data yang digunakan dalam penelitian ini adalah data kuantitatif. Menurut Sugiyono (2017:13) Data Kuantitatif adalah data yang berwujud angka-angka.

Hal ini dilakukan dengan cara mengumpulkan datadata yang merupakan faktor pendukung terhadap pengaruh antara variabel-variabel yang bersangkutan dengan cara membagikan kuesioner kemudian dianalisis dengan menggunakan alat uji statistik.

Sedangkan sumber data yang digunakan dalam penelitian ini adalah berupa data primer, yaitu merupakan data yang diperoleh secara langsung dari objek yang diteliti. Data diperoleh melalui kuesioner kepada beberapa pelaku usaha sentra UMKM di Kota Bandung.

Pengertian data primer oleh Anwar Sanusi (2011: 104) menyatakan bahwa, "Data primer adalah data yang pertama kali dicatat dan dikumpulkan oleh peneliti."

Dalam penelitian ini data yang dipergunakan bersumber dari yang langsung diperoleh oleh peneliti yaitu berupa data primer dan data sekunder, untuk lebih jelasnya sebagai berikut: Menurut Danang Sunyoto (2013). Data primer yaitu data yang diperoleh secara langsung dari 
responden (objek penelitian). Data primer dapat diperoleh melalui wawancara, kuisioner dan observasi lapangan berdasarkan jadwal penelitian.

Menurut Danang Suyanti (2013). Data sekunder diperoleh melalui data yang telah diteliti dan dikumpulkan oleh pihak lain yang berkaitan dengan masalah penelitian, seperti: jumlah pemilik UMKM Sentra di setiap Kecamatan di Kota Bandung yang berasal dari Dinas Perdagangan dan Perindustrian Kota Bandung, peraturanperaturan yang berhubungan tarif $\mathrm{PPh}$ final untuk UMKM

\section{Teknik Penarikan Sampel}

Menurut Sugiyono (2017:80) menyatakan bahwa populasi adalah sebagai berikut:"Wilayah generalisai yang terdiri atas : objek atau subjek yang mempunyai kualitas dan karakteristik tertentu yang ditetapkan oleh peneliti untuk dipelajari dan kemudian ditarik kesimpulannya."

Berdasarkan pengertian di atas, maka yang menjadi populasi dalam penelitian ini adalah jumlah pelaku usaha sentra UMKM yang tersebar di beberapa kecamatan di Kota Bandung yaitu 1.235 pelaku usaha sentra.

Definisi sampel menurut Sugiyono (2017:81) adalah:"Sampel adalah bagian dari jumlah dan karakteristik yang dimiliki oleh populasi tersebut".

Penentuan sampel ditentukan dengan menggunakan ketentuan rumus Slovin (Sujarweni, 2016:8) sebagai berikut :

$n=\frac{N}{1+N \alpha^{2}}$

Keterangan :

$n=$ ukuran sampel

$N=$ ukuran populasi

$\alpha=$ persen kelonggaran ketidaktelitian karena kesalahan pengambilan sampel yang masih dapat ditolerir atau diinginkan, dalam penelitian ini adalah 10\%.

Berdasarkan jumlah pelaku usaha sentra UMKM yang tersebar di beberapa kecamatan di Kota Bandung sebesar 1.235 pelaku usaha sentra dengan margin of error sebesar $10 \%$ adalah:

$\begin{array}{ll}\mathrm{n} & =\frac{N}{1+N(\alpha)^{2}} \\ \mathrm{n} & =\frac{1.235}{1+1.235(0,1)^{2}} \\ \mathrm{n} & =\frac{1.235}{1+1.235(0,01)} \\ \mathrm{n} & =\frac{1.235}{1+12,35} \\ \mathrm{n} & =\frac{1.235}{13,35} \\ \mathrm{n} & =92,5 \\ \mathrm{n} & =93\end{array}$

Jadi jumlah sampel yang digunakan dalam penelitian ini sebanyak 93 pelaku usaha sentra UMKM di Kota Bandung

\section{HASIL DAN PEMBAHASAN}

\section{Gambaran Umum Perusahaan}

\section{Sentra Sepatu Cibaduyut}

Sentra Industri Sepatu Cibaduyut terletak di Jalan Raya Cibaduyut, Kecamatan Bojongloa Kidul, Bandung.Sentra ini terbentuk dari 577 unit IKM yang memproduksi berbagai jenis sepatu seperti Sepatu Keds, Vantofel, sepatu wanita, sepatu anak dll. Kapasitas produksi per tahunnya sebanyak 3.114.022 pasang dengan nilai investasi Rp 19 milyar.Sentra ini telah menyerap 3.008 tenaga kerja. Keunggulan sentra industri ini yaitu teknik pembuatan seputa secara hand made. (sentraindustribandung.com, 2012)

\section{Sentra Bengkel Las, Bubut Kebon Waru}

Sentra Bengkel Las, Bubut Kebon Waru terletak di Jalan Bogor Kecamatan Batununggal. Di sentra tersebut terdapat 104 unit usaha dari berbagai macam industri las maupun bubut, misalkan pembuatan canopi, rolling door, pagar, teralis yang berdiri tahun 1967 dan terkenal dengan nama Pasar Gupeti. Dan jumlah karyawan sebanyak 210 orang.

\section{Sentra Boneka Sukamulya}

Sentra Industri Boneka Sukamulya terletak di Jalan Sukamulya, Kecamatan Sukajadi, Bandung. Sentra ini terdiri dari kurang lebih 17 pengrajin boneka.Kapasitas produksi per tahunnya sebanyak 768.940 unit dengan nilai investasi Rp 2,691 milyar dan menyerap tenaga pekerja sebanyak 212 orang.Keunggulan sentra industri ini yaitu memiliki kualitas dan harga yang bersaing. (sentraindustribandung.com, 2012)

\section{Sentra Boneka Warung Muncang}

Sentra boneka di daerah ini sudah berdiri sejak 20 tahun lalu. Endar, salah satu perajin, bilang, membuat boneka merupakan salah satu bentuk keterampilan tangan yang membutuhkan ketelitian dan kerajinan.cara membuat boneka bermacammacam. Namun pada intinya tetap membutuhkan keterampilan tangan dalam menjahit secara manual. Menurutnya, ada lima langkah sederhana membuat boneka. mengatakan, permintaan bisa naik ketika hari libur atau momen liburan. Pada saat-saat itulah, perajin boneka ketiban berkah, lantaran penjualan bonekanya bisa naik hingga dua kali lipat. Ini lantaran permintaan pasokan boneka dari toko-toko grosir di Bandung meningkat pula. Omset rata-rata dia per bulan sekitar Rp 20 juta sampai Rp 40 juta. Bila liburan tiba, omzet bisa melonjak hingga Rp 50 juta ke atas. Para perajin boneka di sini memang sangat bergantung 
pada pesanan toko boneka grosir di wilayah tersebut. Mereka sangat jarang menjual ke pihak lain di luar Kota Bandung.

\section{Sentra Gorengan Tempe Leuwi Panjang}

Sentra oleh-oleh di Jalan Raya Leuwi Panjang, Bandung, selalu ramai pembeli. Keripik tempe menjadi salah satu penganan khas yang paling banyak diburu pembeli dari pusat oleh-oleh ini. Para pedagang mendapatkan bahan baku tempe dari warung, pasar atau pabrik tempe yang dekat dengan lokasi usaha mereka. Sentra oleh-oleh di Jalan Raya Leuwi Panjang, Kecamatan Bojongloa Kidul, Bandung, sudah sangat kesohor. Letaknya yang strategis dan harganya yang murah membuat pusat oleh-oleh ini selalu ramai diserbupengunjung

\section{Jean's Cihampelas}

Sentra Industri Perdagangan Jeans Cihampelas terletak di Jalan Cihampelas, Kecamatan Coblong, Bandung. Sentra ini terdiri dari 59 unit IKM yang menjual berbagai jenis jeans dengaan omzet penjualan sebesar sebesar Rp 227,55 juta per hari. Sentra ini telah menyerap 352 orang tenaga kerja. Keunggulan sentra industri ini yaitu dikenal menjual jeans dengan modelmodel yang selalu up to date.(sentraindustribandung. com, 2012)

\section{Sentra Kaos dan Sablon Suci}

Sentra Industri Kaos dan Sablon Suci terletak di Jalan Surapati dan Jalan PHH. Mustofa, Kecamatan Cibeunying Kidul, Bandung. Sentra ini terdiri dari 409 unit IKM yang memproduksi berbagai macam jenis sablon kaos. Kapasitas produksi per tahunnya sebanyak 177.300 lusin dengan nilai investasi sebesar Rp 115,403 milyar. Sentra ini telah menyerap tenaga kerja sebanyak 2.721 orang. Keunggulan sentra industri ini yaitu memiliki jangkauan pasar yang luas dan telah di kenal di seluruh kota di Indonesia. (sentraindustribandung.com, 2012)

\section{Karakteristik Responden}

Analisis karakteristik responden digunakan untuk memberikan gambaran terhadapresponden apakah dengan karakteristik yang berbeda-beda akan diperoleh penilaian yang sama atau tidak. Pada penelitian ini, sampel yang menjadi responden adalah tujuh sentra UMKM di Kota Bandung. Data pribadi dari keseluruhan responden yang dipandang relevan dengan permasalahan yang di identifikasi, dikelompokkan ke dalam 4 (empat) kategori, yaitu jenis kelamin, jenis usaha, omset penjualan, dan jenis perusahaan.

Berikut data responden berdasarkan jenis kelamin, jenis usaha, omset penjualan, dan jenis perusahaan.

1. Data responden berdasarkan jenis kelamin yaitu jenis kelamin laki-laki adalah sebanyak 81 responden atau
$87 \%$ dan jenis kelamin perempuan sebanyak 12 atau 13\%. Sehingga dapat disimpulkan bahwa mayoritas responden dalam penelitian ini berdasarkan jenis kelamin adalah jenis kelamin laki-laki yaitu sebesar $87 \%$.

2. Data responden berdasarkan jenis usaha yaitu jenis usaha perdagangan sebanyak 86 responden atau $92 \%$ dan jenis usaha jasa sebanyak 7 atau 8\%. Sehingga dapat disimpulkan bahwa mayoritas pelaku usaha sentra UMKM di Kota Bandung berdasarkan jenis usaha adalah jenis usaha perdagangan yaitu sebesar $92 \%$.

3. Data responden berdasarkan omset penjualan tahunan pelaku usaha UMKM dengan omset penjualan tahunan lebih dari empat milyar delapan ratus juta rupiah adalah sebanyak 7 pelaku usaha sentra UMKM atau $8 \%$ dan omset penjualan tahunan sampai dengan empat milyar delapan ratus juta rupiah adalah sebanyak 93 pelaku usaha sentra UMKM atau 92\%. Sehingga dapat disimpulkan bahwa mayoritas pelaku usaha sentra UMKM di Kota Bandung adalah beromset sampai dengan empat milyar rupiah per tahun atau sebesar $92 \%$.

4. Data responden berdasarkan jenis perusahaan yaitu jenis usaha perusahaan dalam bentuk perorangan sebanyak 80 jenis usaha atau $86 \%$ dan jenis usaha dalam bentuk CV adalah sebanyak 13 atau 14\%. Sehingga dapat disimpulkan bahwa mayoritas pelaku usaha sentra UMKM di Kota Bandung berdasarkan jenis perusahaan adalah jenis usaha dalam bentukperorangan yaitu sebesar $86 \%$.

Tabal 1. Hasil Uji Validitas Persepsi Pelaku Usaha Sentar UMKM Tentang Penerapan Tarif Pajak Final $0,5 \%(\mathrm{X})$

\begin{tabular}{ccccc}
\hline $\begin{array}{c}\text { Variabel } \\
\mathbf{Y}\end{array}$ & $\mathbf{r}_{\text {hitung }}$ & $\mathbf{r}_{\text {tabel }}$ & Signifikansi & Keterangan \\
\hline 1 & 0,706 & 0,204 & 0,000 & Valid \\
2 & 0,423 & 0,204 & 0,000 & Valid \\
3 & 0,599 & 0,204 & 0,000 & Valid \\
4 & 0,653 & 0,204 & 0,000 & Valid \\
5 & 0,681 & 0,204 & 0,000 & Valid \\
6 & 0,680 & 0,204 & 0,000 & Valid \\
7 & 0,653 & 0,204 & 0,000 & Valid \\
8 & 0,497 & 0,204 & 0,000 & Valid \\
9 & 0,371 & 0,204 & 0,000 & Valid \\
10 & 0,561 & 0,204 & 0,000 & Valid \\
11 & 0,441 & 0,204 & 0,000 & Valid \\
12 & 0,658 & 0,204 & 0,000 & Valid \\
13 & 0,676 & 0,204 & 0,000 & Valid \\
\hline
\end{tabular}

Sumber: Data Diolah Menggunakan SPSS 
Berdasarkan Tabel 5 diketahui bahwa item kuesioner untuk mengukur persepsi pelaku usaha sentra UMKM mengenai penerapan tarif pajak Final 0,5(variabel X) mempunyai nilai $\mathbf{r}_{\text {hitung }}$ lebih besar dari $\mathbf{r}_{\text {tabel }}(0,204)$ dengan signifikansi $<0,05$. Hal ini mengindikasikan bahwa item kuesioner tersebut valid dan item kuesioner tersebut dapat digunakan untuk analisis lebih lanjut.

Tabel 2. Hasil Uji Validitas Persepsi Pelaku Usaha Sentra UMKMTentang Perubahan Penerapan Tarif Pajak Final 1\% Menjadi 0,5\% (Y)

\begin{tabular}{ccccc}
\hline $\begin{array}{c}\text { Variabel } \\
\mathbf{Y}\end{array}$ & $\mathbf{r}_{\text {hitung }}$ & $\mathbf{r}_{\text {tabel }}$ & Signifikansi & Keterangan \\
\hline 1 & 0,680 & 0,204 & 0,000 & Valid \\
2 & 0,299 & 0,204 & 0,000 & Valid \\
3 & 0,544 & 0,204 & 0,000 & Valid \\
4 & 0,542 & 0,204 & 0,000 & Valid \\
5 & 0,537 & 0,204 & 0,000 & Valid \\
6 & 0,522 & 0,204 & 0,000 & Valid \\
7 & 0,505 & 0,204 & 0,000 & Valid \\
8 & 0,423 & 0,204 & 0,000 & Valid \\
9 & 0,592 & 0,204 & 0,000 & Valid \\
10 & 0,600 & 0,204 & 0,000 & Valid \\
\hline
\end{tabular}

Sumber: Data Diolah Menggunakan SPSS

Persepsi Pelaku Usaha Sentar UMKM Tentang Penerapan Tarif Pajak Final 0,5\% ( PP No. 23 Tahun 2018)

Berdasarkan data yang diolah dapat diketahui skor rata-rata pernyataan kuesioner mengenai persepsi pelaku usaha sentra UMKM tentang Penerapan tarif Pajak Final 0,5\% (PP No. 23 Tahun 2018) sebesar 651. Skor terendah terdapat pada pernyataan kuesioner nomor 1 mengenai: Saya akan berkontribusi kepada Bangsa dan Negara dalam membayar pajak, pada pernyataan tersebut mendapatkan skor terendah sebesar 95. Skor tertinggi terdapat padapernyataan kuesioner nomor 13mengenai: Dengan Tarif pajak Final yang kecil tersebut, saya akan segera mendaftarkan ke Kantor Pajak setempat untuk memperoleh NPWP (bagi yang belum memiliki NPWP) mendapatkan skor 1,209, hal tersebut dilihat respon akan perubahan tarif Pajak Final 0,5\% cukup baik.Persepsi pelaku usaha sentra UMKM tentang Penerapan tarif Pajak Final 0,5\% (PP No. 23 Tahun 2018) sebesar 651 berada pada kategori Sangat Tidak Setuju.

\section{Responden Yang Menyatakan Sangat Tidak Setuju}

1. Pelaku usaha sentra UMKM Sepatu Cibaduyut dengan omset kurang dari 4,8 milyar rupiah, jenis usaha adalah 7 jenis usaha perdagangan dan jenis perusahaan adalah sebanyak 7 usaha dalam bentuk usaha perorangan serta berjenis kelamin laki laki berjumlah 5 responden dan berjenis kelamin perempuan berjumlah 2 responden.
2. Pelaku usaha sentra UMKM Jean's Cihampelas dengan omset kurang dari 4,8 milyar rupiah, jenis usaha adalah 4 jenis usaha perdagangan dan jenis perusahaan adalah sebanyak 4 usaha dalam bentuk usaha perorangan serta berjenis kelamin laki laki berjumlah 3 responden dan berjenis kelamin perempuan berjumlah 1 responden

3. Pelaku usaha sentra UMKM Boneka Sukagalih dengan omset kurang dari 4,8 milyar rupiah, jenis usaha adalah 2 jenis usaha perdagangan dan jenis perusahaan adalah sebanyak 2 usaha dalam bentuk usaha perorangan serta berjenis kelamin laki laki berjumlah 2 responden dan berjenis kelamin perempuan tidak ada

\section{Responden Yang Menyatakan Tidak Setuju}

1. Pelaku usaha sentra UMKM Sepatu Cibaduyut dengan omset kurang dari 4,8 milyar rupiah, jenis usaha adalah 3 jenis usaha perdagangan dan jenis perusahaan adalah sebanyak 3 usaha dalam bentuk usaha perorangan serta berjenis kelamin laki laki berjumlah 3 responden dan berjenis kelamin perempuan tidak ada

2. Pelaku usaha sentra UMKM Jean's Cihampelas dengan omset kurang dari 4,8 milyar rupiah, jenis usaha adalah 1 jenis usaha perdagangan dan jenis perusahaan adalah sebanyak 1 usaha dalam bentuk usaha perorangan serta berjenis kelamin laki laki berjumlah 1 responden dan berjenis kelamin perempuan tidak ada

3. Pelaku usaha sentra UMKM Boneka Sukagalih dengan omset kurang dari 4,8 milyar rupiah, jenis usaha adalah 1 jenis usaha dalam bentuk CV dan jenis perusahaan adalah sebanyak 1 usaha perorangan serta berjenis kelamin laki laki berjumlah 1 responden dan berjenis kelamin perempuan tidak ada

Berdasarkan penjelasan diatas dapat ditarik kesimpulan bahwa mayoritas responden pelaku usaha sentra UMKM Kota Bandung yang masih minim akan kesadaran dalam mematuhi dan melaksakan peraturan perpajakan adalah pada UMKM di Setra Sepatu Cibaduyut, Sentra Jean's Cihampelas, Sentra Boneka Sukagalih.

Persepsi Pelaku Usaha Sentar UMKM Tentang Perubahan Penerapan Tarif Pajak Final 1\% (PP no. 46 Tahun 2013) Menjadi Tarif Pajak Final 0,5\% (PP No. 23 Tahun 2018)

Berdasarkan data yang diolah dapat diketahui skor rata-rata pernyataan kuesioner mengenai kualitas produk sebesar 512. Skor terendah terdapat pada pernyataan kuesioner nomor 1mengenai: Pajak Final adalah pajak yang akhir tahun pajak tidak perlu membayara lagi (melapor saja) pada pernyataan ini mendapatkn skor terendah sebesar 93. Skor tertinggi terdapat pada pernyataankuesioner nomor 10 mengenai: setiap adanya kebijakan perubahan dalam perpajakan yang berhubungan dengan usaha saya agar disosialisasikan, memperoleh 
skor 930 hal tersebut menunjukkan bahwa adanya sifat kooperatif dari para pelaku usaha sentra UMKM. persepsi pelaku usaha sentra UMKM tentang perubahan tariff Pajak Final 1\% (PP No. 46 Tahu 2018) menjadi tariff Pajak Final) 0,5\% (PP No. 23 Tahun 2018) mendapatkan skor sebesar 930 berada pada kategori Sangat Tidak Setuju.

\section{Responden Yang Menyatakan Sangat Tidak Setuju}

1. Pelaku usaha sentra UMKM Sepatu Cibaduyut dengan omset kurang dari 4,8 milyar rupiah, jenis usaha adalah 5 jenis usaha perdagangan dan jenis perusahaan adalah sebanyak 5 usaha dalam bentuk usaha perorangan serta berjenis kelamin laki laki berjumlah 4 responden dan berjenis kelamin perempuan berjumlah 1 responden.

2. Pelaku usaha sentra UMKM Jean's Cihampelas dengan omset kurang dari 4,8 milyar rupiah, jenis usaha adalah 1 jenis usaha perdagangan, 1 jenis usaha jasa dan jenis perusahaan adalah sebanyak 2 usaha dalam bentuk usaha perorangan serta berjenis kelamin laki laki berjumlah 2 responden dan berjenis kelamin perempuan tidak ada

3. Pelaku usaha sentra UMKM Boneka Sukagalih dengan omset kurang dari 4,8 milyar rupiah, jenis usaha adalah 2 jenis usaha perdagangan dan jenis perusahaan adalah sebanyak 2 usaha dalam bentuk usaha perorangan serta berjenis kelamin laki laki berjumlah 2 responden dan berjenis kelamin perempuan tidak ada

4. Pelaku usaha sentra UMKM Kaos dan Sablon Suci dengan omset kurang dari 4,8 milyar rupiah, jenis usaha adalah 1 jenis usaha jasa dan jenis perusahaan adalah sebanyak 1 usaha dalam bentuk usaha perorangan serta berjenis kelamin laki laki berjumlah 1 responden dan berjenis kelamin perempuan tidak ada

\section{Responden Yang Menyatakan Tidak Setuju}

1. Pelaku usaha sentra UMKM Sepatu Cibaduyut dengan omset kurang dari 4,8 milyar rupiah, jenis usaha adalah 6 jenis usaha perdagangan, 1 jenis usaha jasa dan jenis perusahaan adalah sebanyak 7 usaha dalam bentuk usaha perorangan serta berjenis kelamin laki laki berjumlah 6 responden dan berjenis kelamin perempuan berjumlah 1 responden
2. Pelaku usaha sentra UMKM Jean's Cihampelas dengan omset kurang dari 4,8 milyar rupiah, jenis usaha adalah 3 jenis usaha perdagangan dan jenis perusahaan adalah sebanyak 3 usaha dalam bentuk usaha perorangan serta berjenis kelamin laki laki berjumlah 3 responden dan berjenis kelamin perempuan tidak ada

Berdasarkan penjelasan diatas dapat ditarik kesimpulan bahwa mayoritas responden pelaku usaha sentra UMKM Kota Bandung yang masih minim akan pengetahuan dalam peraturan perpajakan adalah pada pelaku usaha sentra UMKM di Sentra Sepatu Cibaduyut, Sentra Sukagalih, Sentra Jean's Cihampelas dan Sentra Boneka Sukagalih dan Sentra Kaos dan Sablon Suci.

Tabel 3. Hasil Uji Koefisien Korelasi

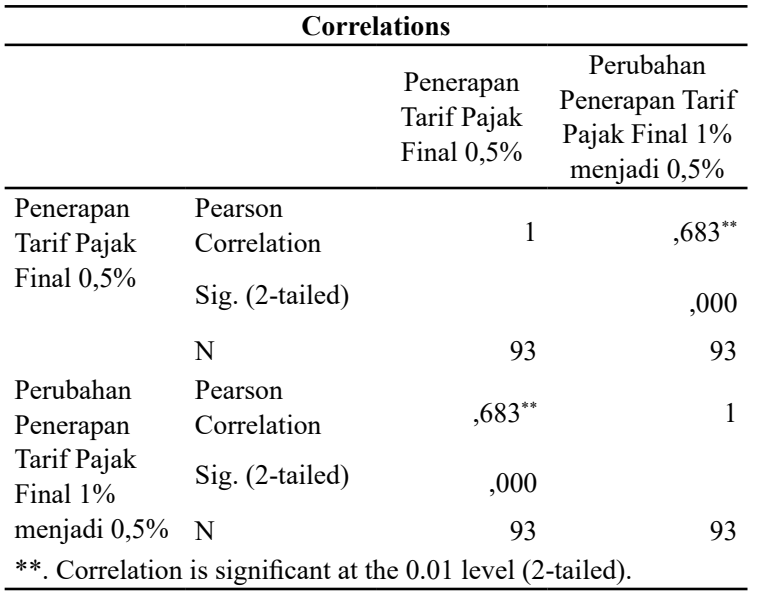

Sumber: Data Diolah Menggunakan SPSS

Berdasarkan hasil perhitungan di atas, dapat diketahui bahwakorelasi antarapersepsi pelaku usaha sentra UMKM tentang peneraoab tarif Pajak Final 0,5\% (X1) denganpersepsi pelaku usaha sentra UMKM tentang Perubahan Penerapan Tarif Pajak Final 1\% menjadi 0,5\% (Y) sebesar 0,683. Hal tersebut menunjukkan bahwa terdapat korelasi positif yang kuat antara persepsi pelaku usaha sentra UMKM tentang peneraoab tarif Pajak Final 0,5\% (X1) denganpersepsi pelaku usaha sentra UMKM tentang Perubahan Penerapan Tarif Pajak Final 1\% menjadi $0,5 \%(\mathrm{Y})$.

Tabel 4. Hasil Uji Linearitas

\begin{tabular}{|c|c|c|c|c|c|c|c|}
\hline \multicolumn{8}{|c|}{ ANOVA Table } \\
\hline & & & $\begin{array}{l}\text { Sum of } \\
\text { Squares }\end{array}$ & df & Mean Square & $\mathrm{F}$ & Sig. \\
\hline \multirow{5}{*}{$\begin{array}{l}\text { Perubahan Penerapan Tarif } \\
\text { Pajak Final } 1 \% \text { menjadi } 0,5 \% \\
* \text { Penerapan Tarif Pajak Final } \\
0,5 \%\end{array}$} & Between & (Combined) & 1007,118 & 24 & 41,963 & 5,118 &, 000 \\
\hline & Groups & Linearity & 730,722 & 1 & 730,722 & 89,124 &, 000 \\
\hline & & $\begin{array}{l}\text { Deviation from } \\
\text { Linearity }\end{array}$ & 276,396 & 23 & 12,017 & 1,466 & ,114 \\
\hline & \multicolumn{2}{|c|}{ Within Groups } & 557,527 & 68 & 8,199 & & \\
\hline & \multicolumn{2}{|l|}{ Total } & 1564,645 & 92 & & & \\
\hline
\end{tabular}


Berdasarken hasil uji linearitas pada otput tabel "Anova Table" di atas, diketahui bahwa nilai Sig. Deviation From Linearity sebesar 0,114. Karena nilai Sig 0,114>0,05 maka dapat disimpulkan bahwa Ho ditolak dan Ha diterima, artinyaterdapat hubungan linier antara persepsi pelaku usaha sentra UMKM tentang peneraoab tarif Pajak Final 0,5\% (X1) denganpersepsi pelaku usaha sentra UMKM tentang Perubahan Penerapan Tarif Pajak Final 1\% menjadi 0,5\%(Y).

\section{Persepsi Pelaku Usaha Sentra UMKM Tentang Penerapan Tarif Pajak Final 0,5\% (PP No. Tahun 2018)}

Berdasarkan penelitian deskriptif yang telah dilakukan bahwa persepsi pelaku usaha Sentra UMKM mengenai penerapan tarif Pajak Final 0,5\% (PP No.23 Tahun 2018) dari sampel yang sudah ditentukan responnya sangat tidak setuju dari hal itu dapat dilihat persepsi para pelaku Usaha UMKM di Kota Bandung tidak setuju dengan adanya penerapan tarif pajak $0,5 \%$, responden yang minim kesadaran akan peraturan perpajakan adalah di sentra Sepatu Cibaduyut, Sentra Boneka Sukagalih dan Sentra Jean's Cihampelas. Akan tetapi sebagian pelaku usaha Sentra UMKM (sampel) kooperatif dengan adanaya kebijakan penerapan Tarif Pajak Final 0,5\%. Penyebab dari kurang nya respon terhadap kebijakan perpajakan karena kurang nya kesadaran masyarakat/pelaku usaha dalam menaati peraturan perpajakan. Berdasarkan uji koefisien korelasi terdapat korelasi positif yang kuat antara persepsi pelaku usaha sentra UMKM tentang peneraoab tarif Pajak Final 0,5\% (X1) denganpersepsi pelaku usaha sentra UMKM tentang Perubahan Penerapan Tarif Pajak Final $1 \%$ menjadi $0,5 \%(\mathrm{Y})$ sebesar 0,683 .

Persepsi Pelaku Usaha Sentra UMKM Tentang Perubahan Penerapan Tarif Pajak Final 1\% (PP No, 46 Tahun 2018) Menjadi Tarif Pajak Final 0,5\% (PP No. 23 Tahun 2018)

Berdasarkan penelitian deskriptif yang telah dilakukan bahwa persepsi pelaku uaha Sentra UMKM mengenai perubahan penerapan tarif Pajak Final 1\% menjadi 0,5\% dari sampel yang sudah ditentukan mendapatkan respon Sangat Tidak Setuju dari hal itu dapat dilihat bahwa persepsi para pelaku Usaha UMKM di Kota Bandung tidak setuju dengan adanya kebijakan perubahan tarif Pajak Final 1\% menjadi tarif Pajak Final 0,5\%, responden yang minim pengetahuan mengenai perpajakan adalah di sentra Sepatu Cibaduyut, Sentra Jean's Cihampelas, Sentra Boneka Sukagalih, Sentra Kaos dan Sablon Suci. Akan tetapi sebagian pelaku usaha Sentra UMKM (sampel) kooperatif dengan adanya kebijakan penerapan perubahan Tarif Pajak Final $1 \%$ menjadi $0,5 \%$. Penyebab dari kurangnya respon terhadapa kebijakan perpajakan dikarenakan kurangnya sosialisasi mengenai kebijakan dan sanksi yang ketat dalam perpajakan. Berdasarkan uji linearitas bahwa persepsi pelaku usaha sentra UMKM tentang penerapan tarif Pajak Final 0,5\% (X1) denganpersepsi pelaku usaha sentra UMKM tentang Perubahan Penerapan Tarif Pajak Final $1 \%$ menjadi $0,5 \%(\mathrm{Y})$ memiliki hubungan secara linear yaitu karena tingkat signifikansi 0,114>0,05.

\section{SIMPULAN}

Berdasarkan hasil penelitian dan pembahasan dapat disimpulkan sebagai berikut:

Berdasarkan penelitian deskriptif yang telah dilakukan bahwa persepsi pelaku usaha Sentra UMKM mengenai penerapan tariff Pajak Final 0,5\% (PP No.23 Tahun 2018) dari sampel yang sudah ditentukan responnya sangat tidak setuju dari hal itu dapat dilihat persepsi para pelaku Usaha UMKM di Kota Bandung tidak setuju dengan adanya penerapan tariff pajak $0,5 \%$, responden yang minim kesadaran akan peraturan perpajakan adalah di sentra Sepatu Cibaduyut, Sentra Boneka Sukagalih dan Sentra Jean's Cihampelas. Akan tetapi sebagian pelaku usaha Sentra UMKM (sampel) kooperatif dengan adanaya kebijakan penerapan Tarif Pajak Final 0,5\%. Penyebab dari kurangnya respon terhadap kebijakan perpajakan karena kurangnya kesadaran masyarakat pelaku usaha dalam menaati peraturan perpajakan. Berdasarkan uji koefisien korelasiter dapat korelasi positif yang kuat antara persepsi pelaku usaha sentra UMKM tentang penerapan tariff Pajak Final 0,5\% (X1) dengan persepsi pelaku usaha sentra UMKM tentang Perubahan Penerapan Tarif Pajak Final $1 \%$ menjadi $0,5 \%$ (Y) sebesar 0,683 .

Berdasarkanpenelitiandeskriptif yang telah dilakukan bahwa persepsi pelaku usaha Sentra UMKM mengenai perubahan penerapan tariff Pajak Final 1\% menjadi 0,5\% dari sampel yang sudah ditentukan mendapatkan respon Sangat Tidak Setuju dari hal itu dapat dilihat bahwa persepsi para pelaku Usaha UMKM di Kota Bandung tidak setuju dengan adanya kebijakan perubahan tariff Pajak Final 1\% menjadi tariff Pajak Final 0,5\%, responden yang minim pengetahuan mengenai perpajakana dalah di sentra Sepatu Cibaduyut, Sentra Jean's Cihampelas, Sentra Boneka Sukagalih, Sentra Kaosdan Sablon Suci. Akan tetapi sebagian pelaku usaha Sentra UMKM (sampel) kooperatif dengan adanaya kebijakan penerapan perubahan Tarif Pajak Final $1 \%$ menjadi $0,5 \%$. Penyebab dari kurangnya respon terhadap kebijakan perpajakan dikarenakan kurangnya sosialisasi mengenai kebijakan dan sanksi yang ketat dalam perpajakan. Berdasarkan uji linearitas bahwa persepsi pelaku usaha sentra UMKM tentangpenerapan tariff Pajak Final 0,5\% (X1) dengan persepsi pelaku usaha sentra UMKM tentang Perubahan Penerapan Tarif Pajak Final 1\% menjadi $0,5 \%(\mathrm{Y})$ memiliki hubungan secara linear yaitu karena tingkat signifikansi 0,114 >0,05. 


\section{UCAPAN TERIMA KASIH}

Pada kesempatan ini, penulis ingin mengucapkan terima kasih yang sedalam-dalamnya kepada berbagai pihak yang telah membantu terwujudnya penelitian ini

1. Dirjen DIKTI yang telah memberikan dana kepada peneliti untuk melaksanakan penelitian ini.

2. Ketua dan Pimpinan akademik launya Sekolah Tinggi Ilmu Ekonomi Indonesia Membangun Bandung

3. Ketua Lembaga Penelitian dan Pengabdian Kepada Masyarakat Sekolah Tinggi Ilmu Ekonomi Indonesia Membangun Bandung dan jajarannya atas dukungan serta bantuan yang diberikan

4. Para pelaku usaha sentra UMKM di Kota Bandung

5. Berbagai pihak yang telah mendukung dna membantu terlaksananya penelitian ini.

\section{DAFTAR PUSTAKA}

Budi, C. (2013). Jutaan UMKM Pahlawan Pajak,Urus Pajak itu Sangat Mudah, Jakarta: Elex Media Komputindo.

Mardiasmo. (2016). Perpajakan-Edisi Terbaru 2016. Yogyakarta: Penerbit Andi.

Peraturan Bank Indonesia Nomor 14/22/PBI/2012 Tentang Pemberian Kredit atau Pembiayaan Oleh bank Umum dan Bantuan Teknis dalam rangka Pengembangan Usaha Mikro, Kecil dan Menengah

PP Nomor 23 Tahun 2018 Tentang Pajak Penghasilan Atas Penghasilan Dari Usaha Yang Diterima Atau Diperoleh Wajib Pajak Yang Memiliki Peredaran Bruto Tertentu

Prabantari, Faizara \& Ardiyanto, D.M. (2017). Implementasi Penghasilan Berdasarkan PP Nomor 46 Tahun 2013 (Studi Kasus UMKM di Jawa Tengah dan Daerah Istimewa Yogyakarta), Diponegoro Journal of Accounting, 6, (4), 1-12.
Sanusi, A. (2011), Metode Penelitian Bisnis, Jakarta: Salemba Empat.

Sari, Diana. (2013). Konsep Dasar Perpajakan. Bandung: PT. Refika Aditama

Sugiyono. (2017). Metode Penelitian Kuantitatif, Kualitatif, dan R\&D. Bandung: Alfabeta

Sugiyono. (2017). Metode Penelitian Kuantitatif, Kualitatif, dan R\&D. Bandung: Alfabeta

Sunyoto, D. (2013). Metodologi Penelitian Akuntansi. Bandung: PT Refika Aditama Anggota Ikapi

Supadmi, N.L \& Suputra, D.G.D. (2016), Persepsi Wajib Pajak Atas Pemberlakuan PP No. 46 tahun 2013 dan Pengaruhnya Pada Kepatuhan (Studi Kasus Pada UMKM di Kota Denpasar), Jurnal Ilmiah Manajemen \& Akuntansi, 22, (2), 95-107.

Syafiqurrahman, M., Budiatmanto, A., Widjajanto, A., Wibawa, A. Setyawan, D. \& Anwar, R.A. (2017), Analisa Pengaruh PP No. 46 Tahun 2013 terhadap Upaya Pemerintah dalam Meningkatkan Perekonomian Indonesia Melalui Sektor UMKM, Journal of Applied Accounting and Taxation, 2, (2), 75-82.

Undang-Undang No. 28 Tahun 2007 Tentang Ketentuan Umum dan Tata Cara Perpajakan

Undang-UndangNo. 36 Tahun. 2008. TentangPajak Penghasilan

Waluyo. (2014). Perpajakan Indonesia. Jakarta: Salemba Empat

Yanuswari, F.V (2016). Analisis Wajib Pajak Sekotor Dagang dan Jasa terhadap Penerapan PP No. 46 Tahu 2013, Jurnal Akuntansi UBHARA, ISSN 2460-7762 